\title{
A Comparison of the Modified Bosworth and Endobutton Techniques in the Surgical Treatment of Rockwood Type III Acromioclavicular Joint Dislocations
}

\author{
Rockwood Tip III Akromiyoklaviküler Eklem \\ Cıııklarının Cerrahi Tedavisinde Modifiye Bosworth \\ ve Endobutton Tekniklerinin Karșılaștırılması
}

\begin{abstract}
Aim: In this study, we aimed to retrospectively compare the long-term clinical and radiological outcomes obtained with the modified Bosworth technique and Endobutton technique in surgical treatment of type II acromioclavicular dislocations.

Materials and Methods: Thirty-two patients (26 males, 6 females) (mean age 37, range 15-78 years) were treated surgically for acromioclavicular joint (ACJ) dislocation. All patients had type III dislocation. Twentytwo patients had right ACJ dislocation and 10 patients had left ACJ dislocation. Of the dislocations, 18 oCcurred due to falls; 9, sports injuries; and 5, traffic accidents. Of the patients, 18 were operated on with the Endobutton technique and 14 with the modified Endobutton technique. Patients were evaluated postoperatively in terms of functional Constant, DASH, and VAS scores and radiologically with coracoclavicular distance (CCD) assessment. The mean follow-up was 52 (37-66) months.

Results: The alignment of the acromioclavicular joint was normal in all patients. No joint degeneration was observed in any patient. Shoulder movements were painless and complete in all patients. The mean postoperative $3^{\text {rd }}, 12^{\text {th }}$, and $24^{\text {th }}$ month Constant scores were found significantly higher for the Endobutton group than for the modified Bosworth group ( $(\mathrm{=}=0.001)$. The mean postoperative $3^{\text {rd }}, 12^{\text {th }}$, and $24^{\text {th }}$ month DASH scores were significantly lower for the Endobutton Group than for the modified Bosworth group $(p=0.003)$. The mean postoperative $3^{\text {rd }}, 12^{\text {th }}$, and $24^{\text {th }}$ month VAS scores were significantly lower for the Endobutton group than for the modified Bosworth group $(p=0.001)$. However, no statistically significant difference was found between the mean preoperative and postoperative CCD values of the two groups $(p=0.104)$

Discussion and Conclusion: The Endobutton technique is a good alternative to the modified Bosworth technique in the surgical treatment of acromioclavicular dislocations.

Keywords: acromioclavicular dislocation; Endobutton technique; modified Bosworth technique
\end{abstract}

Öz

Amaç: Bu çalıșmada tip III akromiyoklaviküler çıkıkların cerrahi tedavisinde modifiye Bosworth tekniğinin ve Endobutton tekniğinin uzun dönem klinik ve radyolojik sonuçlarını retrospektif olarak karșlaștırmak amaçlanmıștır.

Gereç ve Yöntemler: Otuz iki hasta (26 erkek, 6 kadın) (ortalama yaș 37, dağılım 15-78 yıl) akromiyoklaviküler eklem (AKE) çıkığı nedeniyle cerrahi yolla tedavi edildi. Tüm hastalarda tip III çıkık vardı. Yirmi iki hastada sağ AKE çı। ı̆ı, 10 hastada sol AKE çıı̆ğı mevcuttu. Çıkıkların 18'i düșme, 9'u spor yaralanması, 5'i trafik kazası sonucunda meydana gelmiști. Hastaların 18'i Endobutton tekniği, 14'ü ise modifiye Bosworth tekniği ile opere edildi. Hastalar ameliyat sonrası fonksiyonel Constant, DASH ve VAS skorları üzerinden ve radyolojik olarak da KKM (korakoklaviküler mesafe) ölçümü ile değerlendirildi. Ortalama takip süresi 52 (37-66) ay idi.

Bulgular: Tüm hastalarda akromiyoklaviküler eklem dizilimi normaldi. Hiçbir hastada eklem dejenerasyonu görülmedi. Tüm hastalarda omuz hareketleri ağrısız ve tamdı. Endobutton grubunun ortalama postoperatif 3., 12. ve 24. ay Constant skorları modifiye Bosworth grubununkilerden istatistiksel olarak anlamlı șekilde yüksek bulundu $(p=0,001)$. Endobutton grubunun ortalama postoperatif 3., 12. ve 24. ay DASH skorları modifiye Bosworth grubununkilerden istatistiksel olarak anlamlı șekilde düșüktü $(p=0,003)$. Endobutton grubunun ortalama postoperatif 3. 12. ve 24. ay VAS skorları modifiye Bosworth grubununkilerden istatistiksel olarak anlamlı șekilde düșüktü $(p=0,001)$. İki grubun preoperatif ve postoperatif KKM ortalamaları arasında ise istatistiksel olarak anlamlı fark gözlenmedi $(p=0,104)$.

Tartıșma ve Sonuç: Endobutton tekniği akromiyoklaviküler cıkıkların cerrahi tedavisinde modifiye Bosworth tekniğine karșı iyi bir alternatiftir.

Anahtar Sözcükler: akromiyoklaviküler çıkık; Endobutton tekniği; modifiye Bosworth tekniğ
Zekeriya Okan Karaduman', Zafer Orhan', Yalcin Turhan', Mehmet Arican', Erdem Degirmenci', Ozan Turhal $^{2}$

Department of Orthopedics and Traumatology, Faculty of Medicine, Düzce University

${ }^{2}$ Orthopedics and Traumatology Clinic, Düzce Atatürk State Hospital

Received/Gelis : 16.06.2019 Accepted/Kabul: 19.09.2019

DOI: 10.21673/anadoluklin.636164

Corresponding author/Yazıșma yazarı Zekeriya Okan Karaduman

Düzce Üniversitesi Tıp Fakültesi, Ortopedi ve Travmatoloji Anabilim Dalı, Düzce, Turkey E-mail:karadumano@hotmail.com

\section{ORCID}

Zekeriya Okan Karaduman: 0000-0002-6719-3666 Zafer Orhan: 0000-0002-7426-0740 Yalcin Turhan: 0000-0002-1440-9566 Mehmet Arican: 0000-0002-0649-2339 Erdem Degirmenci: 0000-0002-7988-4261 Ozan Turhal: 0000-0002-1514-5574 


\section{INTRODUCTION}

Acromioclavicular dislocations (ACD) constitute 12\% of all shoulder dislocations (1). Acromioclavicular joint (ACJ) is one of the most important stabilizers of the shoulder and has crucial functions in shoulder and arm movements (1). ACDs are frequently seen after sports injuries (2) and five times more common in men (3). The ACJ is generally stabilized by two ligaments: acromioclavicular ligaments, which are responsible for horizontal stability, and coracoclavicular ligaments, responsible for vertical stability $(4,5)$. Tossy and Allman classified ACDs as type I, II, and III dislocations $(6,7)$. Rockwood updated this classification in 1984 by adding the types IV, V, and VI (8). Type I and II dislocations are treated conservatively (3). In type III dislocations, coracoclavicular ligaments are also torn. Although there is no generally accepted treatment for type III dislocations, surgical treatment is mostly applied in young and active patients with physically demanding jobs (9). The aim of this study was to retrospectively evaluate the radiological and functional outcomes in patients with type III ACJ dislocations fixed using the Endobutton and modified Bosworth techniques.

\section{MATERIALS AND METHODS}

This study was approved (2019/220) by the Research Ethics Committee of the Duzce University Faculty of Medicine and was conducted in accordance with the principles of the Declaration of Helsinki. A total of 32 patients (26 males, 6 females; mean age 37, range 1578 years) who underwent surgical treatment for $\mathrm{ACJ}$ dislocation between 2010 and 2016 were evaluated.

The study included patients with radiologically diagnosed Rockwood type III acute ACJ dislocations and an injury duration of $<3$ weeks. Patients with previous shoulder injuries or shoulder surgery were excluded.

There were no additional pathologies. The injury was on the right side in 22 patients and on the left side in 10 patients. The cause of dislocation was falls in 18 patients, sports injuries in 9 patients, and traffic accidents in 5 patients. Eighteen patients were operated on with the Endobutton technique (ZipTighFixation Device, Biomet, Warsaw, IN) and 14 patients with the modified Bosworth technique. The mean follow-up period was 52 (range 37-66) months. Functional evaluation was performed using Constant, Disability of Arm, Shoulder and Hand (DASH), and Visual Analog Scale (VAS) scores pre- and postoperatively. In the radiological evaluation, the vertical distance between the anteroinferior border of the clavicle and the superior border of the coracoid projection (coracoclavicular distance) was compared on preoperative anteroposterior X-ray (AP X-ray).

\section{Surgical procedure}

A 3-cm transverse incision was made from the ACJ to the clavicle while the patient was in a semi-supine position under general anesthesia. The ACJ was placed in its anatomical position using a Kirschner wire (Kwire). In the modified Bosworth technique, the K-wire was first passed through the clavicle and coracoid. It was then drilled using a $4.5-\mathrm{mm}$ cannulated drill. The ACE was fixed using a semi-grooved spongious screw and washer of appropriate length (Figure 1 A-B). The position of the screw and joint was checked via scopy, and the K-wire was withdrawn. In the Endobutton technique, after the joint was reduced, a 2.4$\mathrm{mm}$ guide wire was passed through the clavicle and the chorocoid. The clavicle and chorocoid were then drilled using a $4.5-\mathrm{mm}$ cannulated drill. The Endobutton (ZipTighFixation Device, Biomet) was placed under the chorocoid using a cannulated pusher and checked via scopy. It was brought to the appropriate tension to ensure anatomic reduction of the joint (Figure 2 A-B). A shoulder-arm strap was used for 3 weeks by the patients. Postoperatively, pendular exercise was started for all patients on the first day. Passive and active exercises were started after 3 weeks. Postoperatively, the patients were allowed to use their upper extremities to meet their daily needs.

\section{Statistical analysis}

Statistical analysis was performed using the NCSS (Number Cruncher Statistical System) 2007 software (Utah, USA). In addition to descriptive statistics (mean, standard deviation, median, and interquartile range), the Shapiro-Wilk normality test was used to check the distribution of variables. One-way analysis of variance (ANOVA) was performed for comparison of normally distributed variables over time, and the Newman-Keuls multiple comparison test was used for subgroup comparisons. The independent samples 
Table 1. General patient characteristics

\begin{tabular}{|c|c|c|c|c|}
\hline \multicolumn{2}{|c|}{ Surgical technique } & Modified Bosworth group & Endobutton group & \multirow{2}{*}{$\frac{\mathbf{p}}{0.164^{\star}}$} \\
\hline Age & & $45.36 \pm 16.35$ & $37.44 \pm 14.95$ & \\
\hline \multirow{2}{*}{ Sex } & Male & $\% 85.71$ & $\% 77.78$ & \multirow{2}{*}{$0.568+$} \\
\hline & Female & $\% 1.29$ & $\% 22.22$ & \\
\hline \multicolumn{2}{|c|}{ Follow-up (months) } & $41.14 \pm 4.31$ & $54.89 \pm 5.78$ & $0.0001^{\star}$ \\
\hline \multicolumn{5}{|c|}{$\begin{array}{l}\text { * The independent samples t-test } \\
+ \text { chi-square test }\end{array}$} \\
\hline & & Modified Bosworth group & Endobutton group & $\mathbf{p}^{*}$ \\
\hline \multirow{5}{*}{ Constant score } & Preoperative & $50.50 \pm 4.74$ & $53.72 \pm 5.11$ & 0.078 \\
\hline & Postoperative $3^{\text {rd }}$ month & $58.50 \pm 2.68$ & $68.39 \pm 3.68$ & 0.001 \\
\hline & Postoperative $12^{\text {th }}$ month & $68.14 \pm 3.48$ & $83.17 \pm 4.11$ & 0.001 \\
\hline & Postoperative $24^{\text {th }}$ month & $82.57 \pm 4.97$ & $92.67 \pm 2.93$ & 0.001 \\
\hline & $\mathrm{p} \ddagger$ & 0.001 & 0.001 & \\
\hline \multirow{5}{*}{ DASH } & Preoperative & $118.57 \pm 9.65$ & $115.17 \pm 5.56$ & 0.219 \\
\hline & Postoperative $3^{\text {rd }}$ month & $102.86 \pm 5.38$ & $96.28 \pm 5.93$ & 0.003 \\
\hline & Postoperative $12^{\text {th }}$ month & $87.86 \pm 5.43$ & $72.17 \pm 7.33$ & 0.001 \\
\hline & Postoperative $24^{\text {th }}$ month & $43.93 \pm 3.27$ & $35.78 \pm 2.65$ & 0.001 \\
\hline & $\mathrm{p} \ddagger$ & 0.001 & 0.001 & \\
\hline \multirow{5}{*}{ VAS } & Preoperative & $88.57 \pm 2.95$ & $87.11 \pm 2.85$ & 0.167 \\
\hline & Postoperative $3^{\text {rd }}$ month & $79.14 \pm 3.04$ & $72.61 \pm 2.50$ & 0.001 \\
\hline & Postoperative $12^{\text {th }}$ month & $63.93 \pm 4.89$ & $45.78 \pm 9.21$ & 0.001 \\
\hline & Postoperative $24^{\text {th }}$ month & $36.50 \pm 4.69$ & $20.11 \pm 4.55$ & 0.001 \\
\hline & $\mathrm{p} \ddagger$ & 0.001 & 0.001 & \\
\hline \multirow{5}{*}{$\mathrm{CCD}$} & Preoperative & $20.36 \pm 2.90$ & $22.06 \pm 2.80$ & 0.104 \\
\hline & Postoperative $3^{\text {rd }}$ month & $9.07 \pm 1.07$ & $10.78 \pm 0.88$ & 0.001 \\
\hline & Postoperative $12^{\text {th }}$ month & $9.57 \pm 1.09$ & $11.44 \pm 1.04$ & 0.001 \\
\hline & Postoperative $24^{\text {th }}$ month & $10.79 \pm 1.53$ & $12.17 \pm 1.58$ & 0.019 \\
\hline & $\mathrm{p} \ddagger$ & 0.001 & 0.001 & \\
\hline
\end{tabular}

¥ Paired one-way ANOVA

* The independent samples t-test

t-test and the Mann Whitney U test were used for pairwise comparison of normally distributed groups and non-normally distributed variables, respectively. Chisquare test was used for the comparison of qualitative data. $\mathrm{p}<0.05$ was considered statistically significant.

\section{RESULTS}

Of all participants, $75 \%$ were male and $25 \%$ were female. Sex distribution of the groups was homogeneous $(\mathrm{p}=0.476)$. The mean participant age was $45.36 \pm 16.35$ (18-67) years in the modified Bosworth group and
$37.44 \pm 14.95$ (15-78) years in the Endobutton group. There was no significant difference between the groups in terms of mean age and sex distribution ( $p>0.05)$. The mean follow-up period was significantly longer for the Endobutton group than for the modified Bosworth group $(\mathrm{p}=0.001)$. The general patient characteristics are summarized in Table 1.

The ACJ alignment was normal in all patients. Joint degeneration was not observed in any patient, and shoulder movements were painless and complete in all patients. The DASH, Constant, VAS, and CCD scores obtained at the last follow-up examination were 
compared with the preoperative values. This functional evaluation is summarized in Table 2.

The difference between the preoperative and postoperative DASH scores was significant in both of the Endobutton and modified Bosworth groups $(\mathrm{p}=0.001)$. The difference between the preoperative and postoperative Constant scores was also significant in both groups ( $\mathrm{p}=0.001$ ). The VAS scores were significantly lower in the postoperative period than in the preoperative period $(\mathrm{p}=0.001)$. The mean Constant scores of the Endobutton group in the postoperative $3^{\text {rd }}, 12^{\text {th }}$, and $24^{\text {th }}$ months were significantly higher than those of the modified Bosworth group ( $\mathrm{p}=0.001$ ). The mean DASH scores of the Endobutton group in the postoperative $3^{\text {rd }}, 12^{\text {th }}$, and $24^{\text {th }}$ months were significantly lower than those of the modified Bosworth group ( $\mathrm{p}=0.003$ ). The mean VAS scores of the Endobutton group in the postoperative $3^{\text {rd }}, 12^{\text {th }}$, and $24^{\text {th }}$ months were significantly lower than those of the modified Bosworth group $(\mathrm{p}=0.0001)$. There was no significant difference between the mean preoperative and postoperative CCD scores in both groups ( $\mathrm{p}=0.104)$.

Radiographically, the ACJ alignment was normal in all patients. None of the patients had joint degeneration or significant ossification. Cosmetically, none of the patients had poor scar tissue, and the ACJ was not apparent. Shoulder movements were painless and complete in all patients. None of the patients had to change their jobs or cease their sports activity.

\section{DISCUSSION AND CONCLUSION}

In this study, we evaluated the clinical outcomes of two different fixation methods used in the treatment of type III ACJ dislocations. After a mean follow-up of 52 months, successful and significant functional improvements were recorded in all patients, compared with the preoperative period. No complication developed in any patient, and no patient had to be re-operated on due to ACJ dislocation. The fact that postoperative movement restriction in the shoulder joint did not develop in any patient supports the argument that both treatment methods can be safely used in patients with type III ACJ dislocations.

Studies have shown that conservative treatment provides similar outcomes in terms of muscle strength,
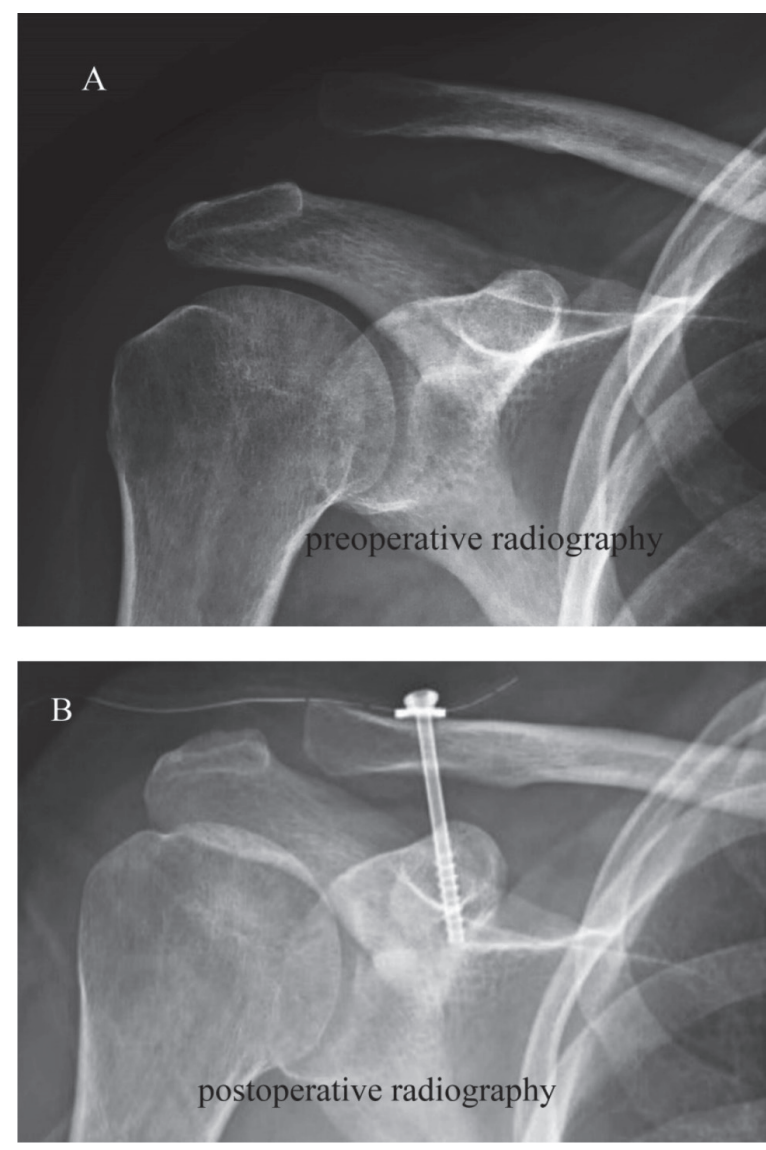

Figure 1. Modified Bosworth technique (A) preoperative and (B) postoperative X-ray.

pain level, range of motion, and functionality, but it does not have any superiority over surgical treatment (10). In a meta-analysis investigating the outcomes of surgical and conservative treatment of Rockwood type III ACJ dislocations, muscle strength, pain level, throwing capacity, and arthrosis development incidence were the same between the conservative and surgical treatments, but cosmetic outcomes were poor with conservative treatment (11). A study evaluating 26 patients who underwent conservative and surgical treatment for type III ACJ dislocation found that conservative treatment was advantageous in terms of returning to work, returning to sports, and immobilization time, whereas surgical treatment was advantageous in terms of full return to work, causing no pain, subjective pain perception of the patient, joint range of motion, functional limitation, cosmetics, and long-term satisfaction (12). We preferred using surgical methods for our patients because our aim was to restore the pre-injury anatomy of the $\mathrm{ACJ}$ (13), and no 

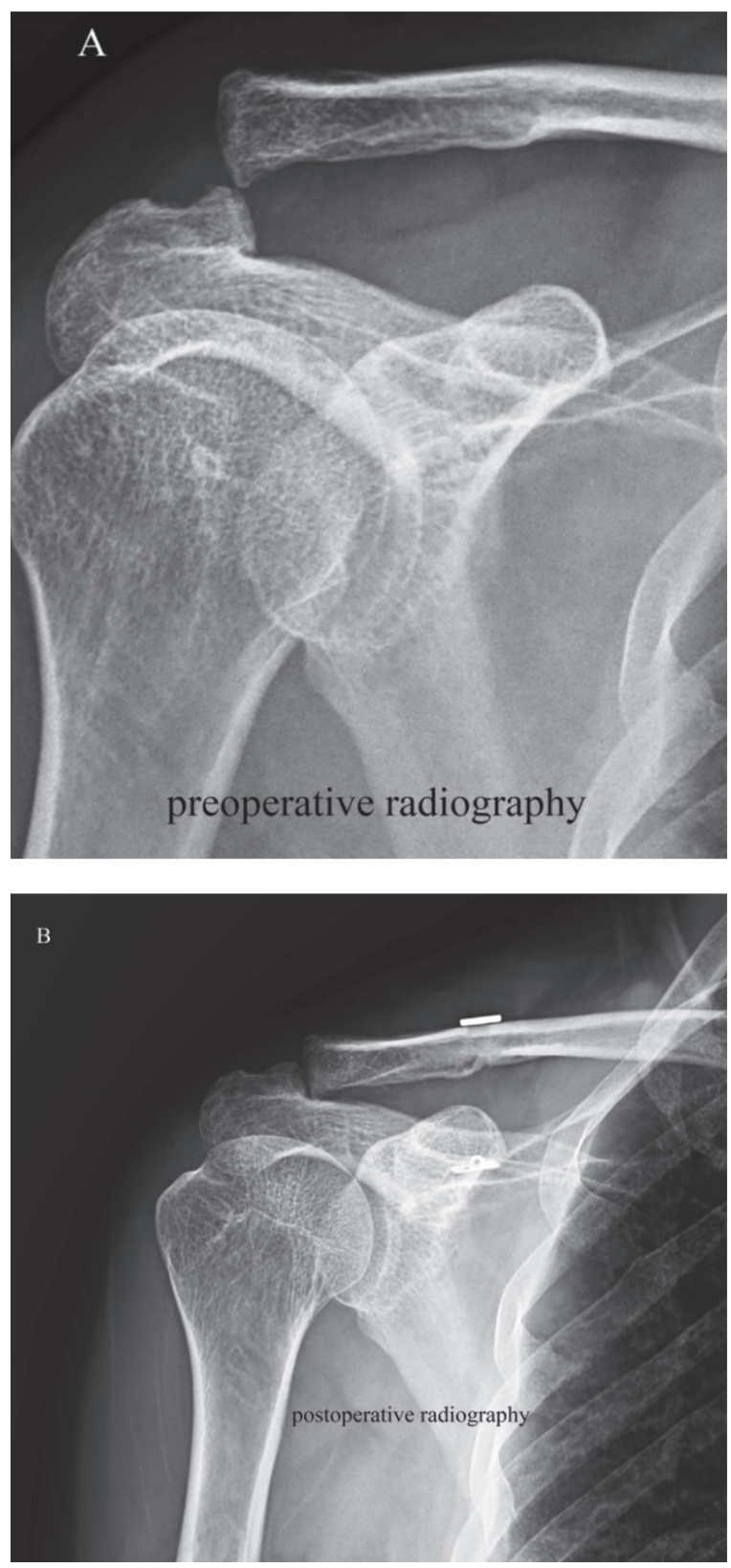

Figure 2. Endobutton technique (A) preoperative and (B) postoperative $\mathrm{X}$-ray.

study in the literature has demonstrated any superiority of conservative treatment over surgical treatment.

Many surgical procedures have been described to treat ACJ dislocations (14), which are in general categorized in two groups: primary repair of the coracoclavicular ligament, and reconstruction of the coracoclavicular ligament (2). Through these techniques, the fixation of the ACJ is performed using a screw, K-wire, or plate. However, infection, ACJ arthritis, or implant failure or migration may develop in association with these techniques (3-5). Coracoclavicular stabilization can be performed using screws, synthetic materials, or cerclage wires. In anatomic ACJ reconstructions performed using various grafts, the robustness is associated with the graft used (8). Coracoclavicular stabilization using lag screws was described by Bosworth in the 1940s. The original technique did not include ligament repair or reconstruction. In the 1990s, Rockwood and Young proposed ligament repair in acute cases and ligament reconstruction in chronic cases by using the Bosworth screw (1). The mechanical performance of the coracoclavicular screw is closest to the mechanical performance of the original ligament. The strength of the coracoclavicular screw is $80 \%$ greater than that of the original ligament if it is passed through two cortices and half the strength of the original ligament if it is passed through a single cortex (15). This demonstrates the importance of correct placement of the screw (16). In our patients, the screws were applied through two cortices (double cortex). After screw application, the appropriateness of the fixation was evaluated on scopy in each patient.

The most common complication of the modified Bosworth technique is the loosening of the screw and re-dislocation of the joint (17). Previous studies have reported that $8.8 \%$ of patients treated using the Bosworth technique develop subluxation (18). In our study, subluxation did not develop in any patient. Despite its biomechanical advantages, screw loosening, infection, and irritation under the screw head have been reported in patients with coracoclavicular screw fixation (19). No infection or irritation was observed in our patients. A limitation of the modified Bosworth technique is the need for a secondary intervention for screw removal. The balance between the early removal of the screw to prevent breakage and the risk of recurrent deformity should be carefully established; otherwise, the deformity recurs, which has been reported to occur at a high rate of $35 \%$. A general recommendation is to remove the screw at 8 weeks (20). In all of our patients, the screws were removed under local anesthesia at the $8^{\text {th }}$ postoperative week, and no screw fractures were observed. Accordingly, fixation using spongious screws in the surgical treatment of ACJ dislocations is an effective method for achieving adequate shoulder function with a low complication rate and low $\mathrm{ACJ}$ arthritis rate. 
In conclusion, we found that both surgical techniques were reliable in the treatment of type III ACJ dislocations, but the outcomes with the easy-to-perform Endobutton technique that does not require secondary surgery (9) were better in terms of functionality and pain level. We also believe that the Endobutton technique is a better surgical option than the Bosworth screw-fixation method because it is associated with lower wound infection rates in the late postoperative period.

\section{Conflict of Interest and Financial Disclosure}

The authors declare that they have no conflict of interest to disclose. The authors also declare that they did not receive any financial support for the study.

\section{REFERENCES}

1. Collins DN. Disorders of the acromioclavicular joint. In: The Shoulder (vol. 4), 4. ed. Philadelphia: Saunders Elsevier; 2009.

2. Rockwood CA Jr.., Williams GR, Young DC. Injuries to the acromioclavicular joint. In: Rockwood CA Jr., Green DP, Bucholz RW, Heckmen JD (ed.), Rockwood and Green's Fractures in Adults (vol. 2), 4. ed. Philadelphia: JB Lippincott-Raven; 1996:1341-413.

3. Lancaster S, Horowitz M, Alonso J. Complete acromioclavicular separations. A comparison of operative methods. Clin Orthop Relat Res. 1987;(216):80-8.

4. Salem KH, Schmelz A. Treatment of Tossy III acromioclavicular joint injuries using hook plates and ligament suture. J Orthop Trauma. 2009;23:565-9.

5. Bargren JH, Erlanger S, Dick HM. Biomechanics and comparison of two operative methods of treatment of complete acromioclavicular separation. Clin Orthop Relat Res. 1978;(130):267-72.

6. Fukuda K, Craig EV, An KN, Cofield RH, Chao EY. Biomechanical study of the ligamentous system of the acromioclavicular joint. J Bone Joint Surg. 1986;68:434-40.

7. Deshmukh AV, Wilson DR, Zilberfarb JL, Perlmutter GS. Stability of acromioclavicular joint reconstruction: biomechanical testing of various surgical techniques in a cadaveric model. Am J Sports Med. 2004;32:1492-8.

8. Grutter PW, Petersen SA. Anatomical acromioclavicular ligament reconstruction: a biomechanical comparison of reconstructive techniques of the acromioclavicular joint. Am J Sports Med. 2005;33:1723-8.

9. Wei HF, Chen YF, Zeng BF. Triple endobuttton technique for the treatment of acute complete acromiocla- vicular joint dislocations: preliminary results. Int Orthop. 2011;35(4):555-9.

10. Schlegel TF, Burks RT, Marcus RL, Dunn HK. A prospective evaluation of untreated acute grade III acromioclavicular separations. Am J Sports Med. 2001;29:699e703.

11. Smith TO, Chester R, Pearse EO, Hing CB. Operative versus non-operative management following Rockwood grade III acromioclavicular separation: a meta-analysis of the current evidence base. J Orthop Traumatol. 2011;12:19e27.

12. Press J, Zuckerman JD, Gallagher M, Cuomo F. Treatment of grade III acromioclavicular separations. Operative versus nonoperative management. Bull Hosp Jt Dis. 1997;56:77-83.

13. Tauber M. Management of acute acromioclavicular joint dislocations: current concepts. Arch Orthop Trauma Surg. 2013;133:985e995.

14. Takase K, Yamamoto K. Changes in surgical procedures for acromioclavicular joint dislocation over the past 30 years. Orthopedics. 2013;36:1277e1282.

15. Harris RI, Wallace AL, Harper GD, Goldberg JA, Sonnabend DH, Walsh WR. Structural properties of the intact and there constructed coracoclavicular ligament complex. Am J Sports Med. 2000;28:103-8.

16. Assaghir YM. Outcome of exact anatomic repair and coracoclavicular cortical lag screw in acute acromioclavicular dislocations. J Trauma Acute Care Surg. 2011;71:50e54.

17. Pavlik A, Csépai D, Hidas P. Surgical treatment of chronic acromioclavicular joint dislocation by modified Weaver-Dunn procedure. Knee Surg Sports Traumatol Arthrosc. 2001;9:307-12.

18. Bektaşer B, Bozkurt M, Öçgüder A, Solak Ş, Oğuz T. Tip III akromiyoklaviküler eklem çıkıklarının modifiye Bosworth tekniği ile cerrahi tedavisi. Ulus Travma Acil Cerrahi Derg. 2004;10:245-9.

19. Bhattacharya R, Goodchild L, Rangan A. Acromioclavicular joint reconstruction using the Nottingham Surgilig: a preliminary report. Acta Orthop Belg. 2008;74:167-72.

20. Bannister GC, Wallace WA, Stableforth PG, Hutson MA. The management of acute acromioclavicular dislocation. A randomized prospective controlled trial. J Bone Joint Surg. 1989;71:848-50. 